\title{
Literature Review: Global Neonicotinoid Insecticide Occurrence in Aquatic Environments
}

\author{
Josephus F. Borsuah ${ }^{1, *}$, Tiffany L. Messer ${ }^{2}$, Daniel D. Snow ${ }^{1}\left(\mathbb{C}\right.$, Steve D. Comfort ${ }^{1}$ \\ and Aaron R. Mittelstet ${ }^{3}$ \\ 1 School of Natural Resources, University of Nebraska-Lincoln, 101 Hardin Hall Lincoln, NE 68583, USA; \\ dsnow1@unl.edu (D.D.S.); scomfort@unl.edu (S.D.C.) \\ 2 Biosystems and Agricultural Engineering, University of Kentucky, 128 CE Barnhart Lexington, \\ KY 40506, USA; tiffany.messer@uky.edu \\ 3 Biological Systems Engineering, University of Nebraska-Lincoln, 200 L.W. Chase Hall Lincoln, \\ NE 68583, USA; amittelstet2@unl.edu \\ * Correspondence: jborsuah2@huskers.unl.edu
}

Received: 1 October 2020; Accepted: 23 November 2020; Published: 2 December 2020

\begin{abstract}
Neonicotinoids have been the most commonly used insecticides since the early 1990s. Despite their efficacy in improving crop protection and management, these agrochemicals have gained recent attention for their negative impacts on non-target species such as honeybees and aquatic invertebrates. In recent years, neonicotinoids have been detected in rivers and streams across the world. Determining and predicting the exposure potential of neonicotinoids in surface water requires a thorough understanding of their fate and transport mechanisms. Therefore, our objective was to provide a comprehensive review of neonicotinoids with a focus on their fate and transport mechanisms to and within surface waters and their occurrence in waterways throughout the world. A better understanding of fate and transport mechanisms will enable researchers to accurately predict occurrence and persistence of insecticides entering surface waters and potential exposure to non-target organisms in agricultural intensive regions. This review has direct implications on how neonicotinoids are monitored and degraded in aquatic ecosystems. Further, an improved understanding of the fate and transport of neonicotinoids aide natural resource practitioners in the development and implementation of effective best management practices to reduce the potential impact and exposure of neonicotinoids in waterways and aquatic ecosystems.
\end{abstract}

Keywords: neonicotinoid insecticides; fate and transport; agriculture; ecosystem

\section{Introduction}

\subsection{Background of Neonicotinoids}

Pesticides are any substance used for controlling, preventing, destroying, repelling, or mitigating a pest. In most instances, the pest is an unwanted weed, insect, fungus, nematode, or rodent. Pesticides are further subdivided into specific groups to signify the particular type of pest the chemical is intended to control. Common examples include herbicides, fungicides, and insecticides [1-5]. Specifically, neonicotinoids have become the fastest-growing insecticide class since the commercialization of organophosphates (OP), pyrethroids, and carbamate insecticides [6]. Neonicotinoids are insecticides that exhibit physicochemical properties, rendering them more useful over other classes of insecticides. This includes having a wide range of application techniques (e.g., foliar, seed treatment, soil drench, and stem applications) and efficacy in controlling sucking and biting insects (i.e., whiteflies, thrips, leaf miners, beetle and lepidopteran species) [7]. 
Neonicotinoids were developed in the late 1980s and introduced into the pesticide market during the 1990s. Imidacloprid is the oldest neonicotinoid and was first approved for use in United States (U.S.) in 1994 and in Canada during 1995 to control insect damage to potatoes, tomatoes, apples, field lettuce, and other greenhouse plants [8]. In contrast, other neonicotinoids (i.e., acetamiprid, thiacloprid, thiamethoxam, and imidacloprid) were not approved for crops grown for human consumption in Europe until 2004 [9]. The use of neonicotinoids has been registered in approximately 120 countries worldwide [10]. There have been tremendous benefits associated with the use of insecticides in the agricultural, public health, forestry, and domestic landscape industries, which contribute greatly to the economies of both developed and developing countries [11]. Among many factors, extensive use of insecticides is partially responsible for increased yield in agricultural production in recent decades. For example, wheat production in the United Kingdom and corn production in the United States has increased in the last three decades [11]. However, its use has been associated with serious health consequences for humans and the environment [11]. Overwhelming evidence has risen over the past decade regarding potentially harmful risks to humans, non-target insects, aquatic invertebrates, and side effects on the natural environment following usage of specific classes of insecticides [12,13].

Recent surface water studies have reported the occurrence of several neonicotinoids, specifically imidacloprid, clothianidin, and thiamethoxam, at various frequencies and concentrations throughout the world [14]. A review investigating surface water in eight countries reported that neonicotinoids were frequently detected in surface water with concentrations ranging between $0.001 \mu \mathrm{g} / \mathrm{L}$ and $320 \mu \mathrm{g} / \mathrm{L}$. These findings have led countries around the world to reduce neonicotinoid use to minimize the potential negative impacts on non-target organisms (e.g., bees and macroinvertebrates [9]. While other researchers have investigated the occurrence of neonicotinoids in aquatic environments and degradation mechanisms under laboratory conditions, a global review regarding neonicotinoid fate and transport mechanisms and degradation in realistic environmental conditions is limited. Therefore, the objective of this study was to provide a comprehensive review of neonicotinoids, with a focus on occurrence and fate and transport mechanisms to and within surface waters. Therefore, we reviewed 55 articles focused on the occurrence and/or fate and transport of neonicotinoids in realistic aquatic environments.

\subsection{Global Economic Impacts and Commercialization}

The growth of neonicotinoids in the global market is supported by their effectiveness for minimizing crop damage. Presently, neonicotinoids occupy approximately one-quarter of the global insecticide market, with $80 \%$ of insecticide use being applied through pre-coated seed treatment [15]. Three of the most commonly used neonicotinoids in agricultural and urban settings include imidacloprid, thiamethoxam, and clothianidin [14]. In 2009, imidacloprid accounted for $41.5 \%$ of the neonicotinoids purchased with a market value of $\$ 2.6$ billion, followed by thiamethoxam and clothianidin at $\$ 627$ and $\$ 439$ million, respectively [6]. However, as of 2014, neonicotinoids were registered in over 120 countries worldwide, out of which thiamethoxam accounted for $25 \%$ of the total global insecticide market with a commercial value of $\$ 3$ billion, while in 2012, imidacloprid and clothianidin were the most used insecticides accounting for $85 \%$ in global insecticides market [10].

\section{Physical and Chemical Structure of Neonicotinoids}

Currently, seven neonicotinoids are commercially available (Table 1). Neonicotinoids have exceptional potency and systemic action for crop protection against insects compared to mammalian organisms [16]. Neonicotinoids act as agonists on the postsynaptic insect nicotinic acetylcholine receptors (nAChRs), biodegradable substituents which have a much higher affinity on insects than mammals [17].

Specifically, the nAChR plays a central role in the mediation of fast excitatory synaptic transmission in an insect's central nervous system [6]. Further, the nAChR has become an important target site in modern crop protection with the discovery and commercialization of neonicotinoids (i.e., 
nereistoxin (4-N,N-dimethylamino-1,2-dithiolane), nithiazine (2-nitromethylenetetrahydro-1,3-thiazine), five-membered ring systems (imidacloprid, thiacloprid), six-membered ring system (thiamethoxam), and noncyclic structures (nitenpyram, acetamiprid, clothianidin, dinotefuran) [6]. The toxins released by these chemicals are considered to be centrally mediated because the symptoms of neonicotinoids are similar to those in nicotine $[18,19]$. The acetylcholine receptors (nAChRs) are members of the superfamily ligand-gated ion channel responsible for rapid excitatory cholinergic neurotransmission [18-20]. $\mathrm{nAChR}$ molecules contain five subunits, each of which contain a dicysteine loop (Cys-loop) with 13 intervening residues in the N-terminal, extracellular domain [21]. They are classified into $\alpha$ subunits and non- $\alpha$ subunits, in which the classification is based on the presence of $\alpha$ or non- $\alpha$.

Table 1. Chemical properties of neonicotinoid class of insecticides (adapted from [22]).

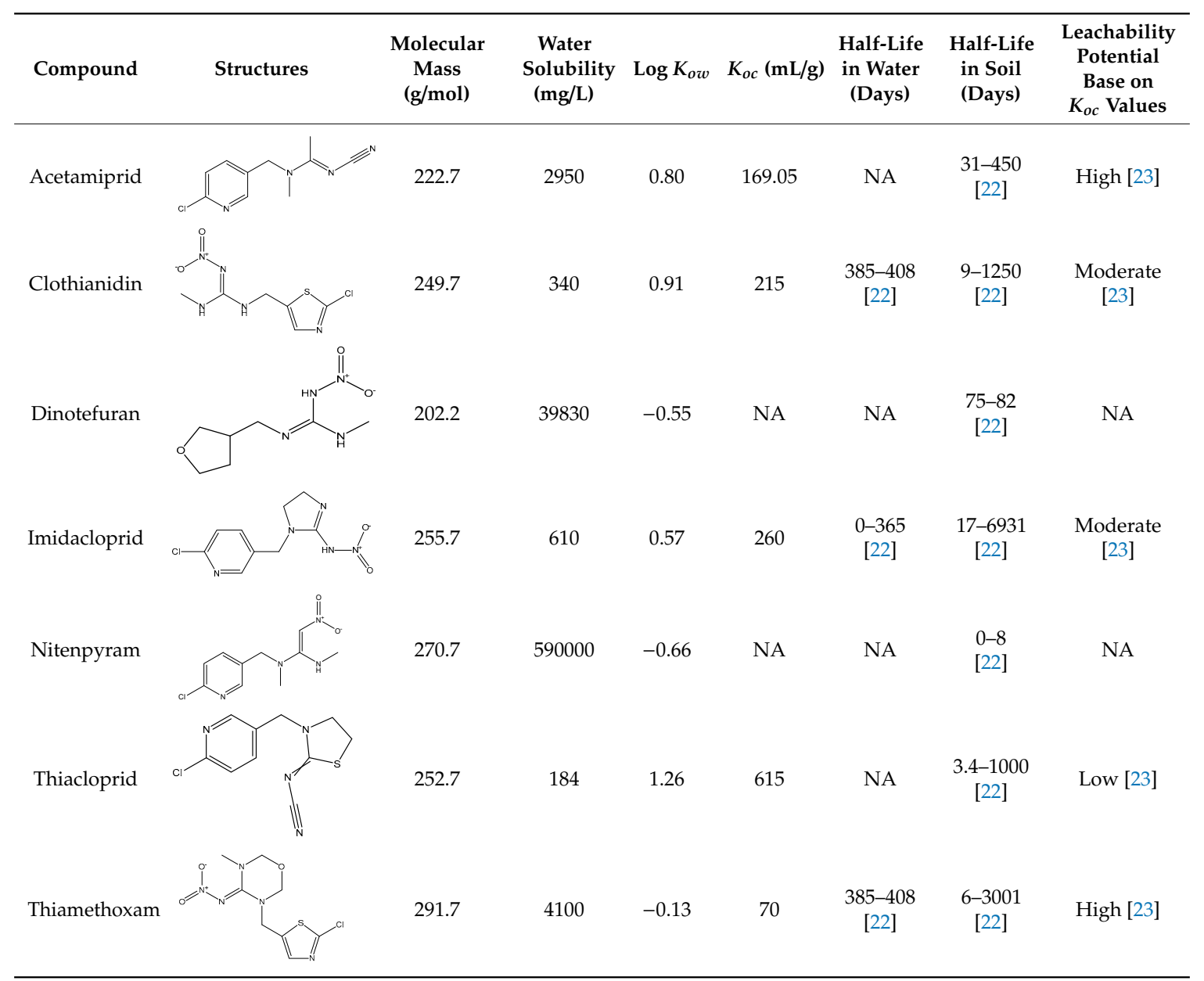

$K_{o w}=$ octanol water partition coefficient; $K_{o c}=$ organic carbon partition coefficient; $K_{d}=$ soil-water partition coefficient.

\section{Application Methods}

Neonicotinoids enter the environment through various application methods. However, the two primary methods are seed treatment and spraying [24]. Each method allows the chemical constituent contained in the compound to directly reach the soil. However, depending on the characteristics of the crop and application method, only $1.6 \%$ to $28 \%$ will be absorbed by the crop, while the rest will remain in the soil and/or be transported to aquatic environments [8,25]. Anaerobic conditions, $\mathrm{pH}$, ultraviolet (UV) light, temperature, and biological activities are environmental conditions that greatly influence the fate and transport of neonicotinoids $[8,26]$. The major transport routes of neonicotinoids to aquatic environments is surface runoff with a small portion of soluble or insoluble fractions transported through snowmelt [27]. 


\subsection{Fate and Transport in Soil Environments}

In the terrestrial environment, soil acts as a sink for most insecticides in both agricultural and urban landscapes [28]. Neonicotinoids enter soil by numerous routes including direct application to the soil through spray drift, seed dressing, and runoff. Once neonicotinoids enter the soil-water environment, they undergo various transport and transformation processes (Figure 1) [28]. Transport processes of neonicotinoids in soil environments include predominately leaching, surface runoff, and plant uptake. Fate and transport pathways of neonicotinoids in soil environments are dependent on the insecticide chemical properties (solubility, leaching potential, volatility, and half-life), soil characteristics (type, texture and formation), and application methods (seed dressing and spraying) $[29,30]$. Neonicotinoids that remain in the soil-water environment undergo biological and photochemical degradation [31].

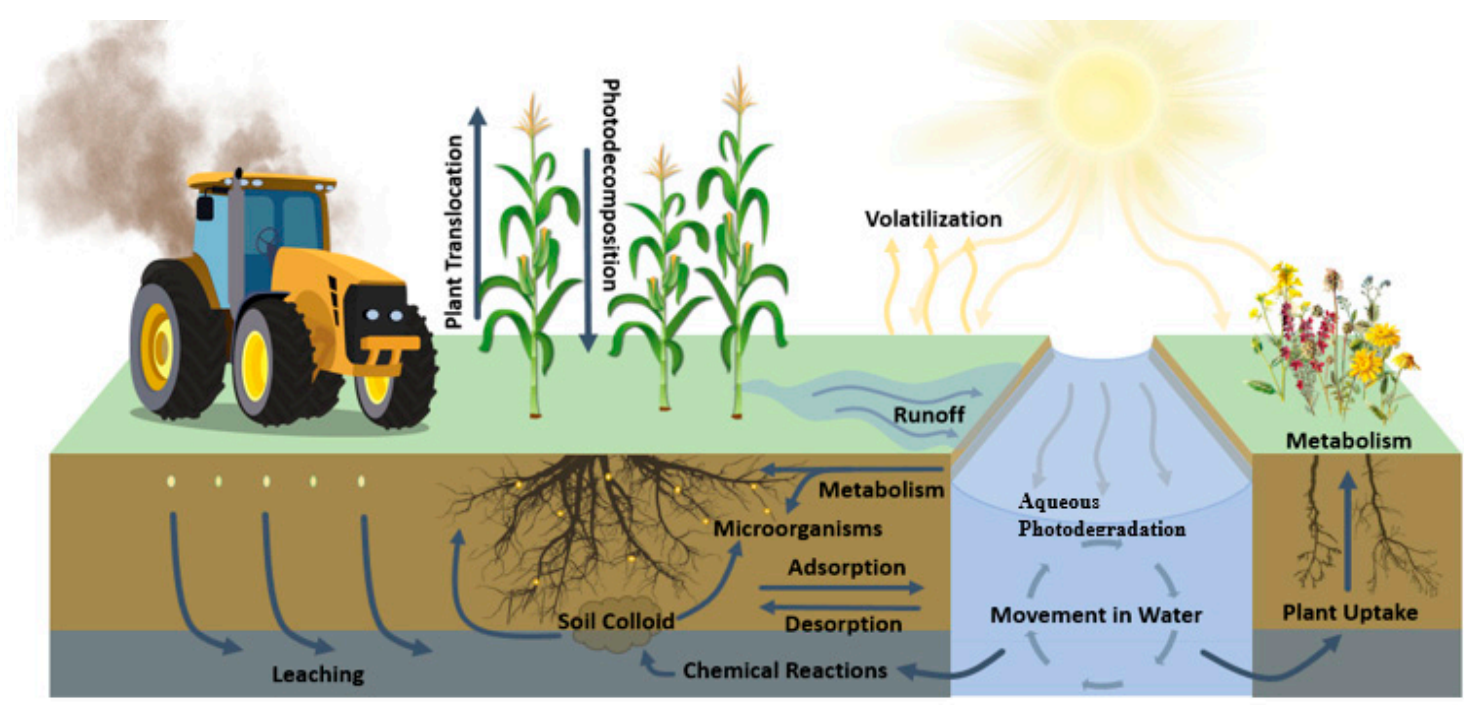

Figure 1. Factors affecting the fate and transport of neonicotinoid insecticides in agroecosystems (adapted from [32]).

Neonicotinoids are small molecules with high water solubility ranging from 184 to 590,000 mg/L and low volatility, which presents concerns for the potential of neonicotinoids to leach into surface and groundwater [22]. To understand leaching behavior of neonicotinoids, multiple studies have been conducted to evaluate the sorption of neonicotinoids in varying soils from around the world [33]. In soils, sorption of neonicotinoids is influenced by organic carbon content (OC), soil textural composition, and temperature [8]. According to [34], the rate of neonicotinoid adsorption increases with temperature and dissolved organic carbon as they compete with neonicotinoids for binding sites on soil particles.

Insecticide leaching through the soil profile is dependent on the physical-chemical properties, insecticide formulation, and soil type. Some classes of neonicotinoids have high leaching potential (Table 1), which results in their ability to freely move through the soil column and enter groundwater or surface water [28,30]. According to [8], they found soils to be the major medium through which groundwater and surface water contamination of neonicotinoids occurred, specifically at application sites (e.g., agricultural fields). Neonicotinoid classes exhibit moderate to high water solubility and low volatility, resulting in their amenability for use as systemic insecticides [22]. In soils, one of the efficient transport methods to determine the leaching potential of organic compounds is by using the organic-carbon partition coefficient $\left(K_{o c}\right)$ and half-life $\left(D T_{50}\right)$ to calculate Groundwater Ubiquity Score (GUS) (displayed in Table 1). The GUS is calculated using the following expression: GUS $=\log _{10}\left(D T_{50}\right) \times\left(4-\log _{10}\left(K_{o c}\right)\right)$, where $\left(D T_{50}\right)$ is the time at which $50 \%$ of the mass of the applied organic compound dissipates, and $\left(K_{o c}\right)$ is the distribution coefficient normalized by the organic matter content [35]. 
Due to the continuous presence of water in many soils, hydrolysis is also a major chemical reaction that influences the transformation of neonicotinoids in the soil environment. In contrast, photolysis is a chemical reaction, resulting in the degradation of neonicotinoids into secondary byproducts by reactions with sunlight. However, in the soil, photodegradation is the least common transformation due to the ability of soils to adsorb radiant energy thus reducing the exposure of sunlight on the compound $[32,36]$.

\subsection{Fate and Transport in Water Environments}

In recent years, insecticides, including neonicotinoids, have contributed both to surface and ground water contamination in waterbodies located within high agricultural regions where frequent use of neonicotinoids has occurred [37]. Between $25.4 \%$ to $80.9 \%$ of neonicotinoids applied to soils undergo some form of degradation; however, that percentage depends on the application rate and soil type [38]. This means approximately $20 \%$ to $75 \%$ of neonicotinoids applied are available for transport to surface waters by runoff or leached into groundwater [36]. Additionally, following insecticide applications sprayer equipment often containing a mixture of the residue may result to offsite runoff and cause negative effect on the environment if not appropriately managed [39]. Further, there is a growing concern regarding groundwater contamination by insecticides used in agricultural industries and urban settings [40]. Neonicotinoids have been found in groundwater in the U.S., Europe, and other regions of the world $[24,41]$. Therefore, understanding how these insecticides reside and degrade in aquatic environments is important. Various factors affect the fate and transport of neonicotinoids in aquatic environments including surface runoff, biological degradation, and aqueous photolysis (Figure 1).

As with other pesticides, neonicotinoids enter waterbodies through diffuse sources including point and non-point sources. Non-point sources include, but are not limited to, agricultural fields, urban lawns, and golf courses. Neonicotinoids are transported in water through tile drains, base flow, seepage, runoff, subsurface drainage, soil eroding from treated field, spray drift, and deposition after volatilization. In comparison, point sources include effluent from wastewater treatment plants and industrial discharges containing neonicotinoids [42]. Factors including high water solubility, long half-life and low $\left(K_{o c}\right)$ of neonicotinoids (as highlighted in Table 1 ) enhance their persistence and mobility in soil [28].

\subsection{Neonicotinoid Degradation Pathways}

Biotic and abiotic degradation processes contribute to environmental persistence of neonicotinoids. The half-life of neonicotinoids varies depending on physiochemical conditions (i.e., organic matter content, soil texture, residence time) prior to undergoing complete degradation [30]. For instance, in middle and high latitudes, the half-life of neonicotinoids are longer than in tropical regions because of a shorter photoperiod and lower photo intensity and temperature [30]. The half-life of imidacloprid in soil ranges from 28 to 1250 days in comparison to 7 to 353 days for thiamethoxam and 148 to 6931 days for clothianidin [3]. However, in subtropical humid climates the half-life of imidacloprid has been observed to be shorter in soil [30]. In contrast, in aquatic environments, the half-life of neonicotinoids ranges from 0 to 40.3 days for clothianidin, 0 to 30 days for imidacloprid, and 0 to 36.6 days for thiamethoxam [2].

In water, neonicotinoids undergo two major degradation processes: hydrolysis, and photolysis. Hydrolysis is the chemical transformation in which the compound reacts with water, resulting in the separation of the water molecule. For the process of hydrolysis to be successful, the chemical compound would have a functional group in their structure, which provides the compound the ability to react with water [32] and is an important factor that influences the fate and transport of neonicotinoids in water [36]. In contrast, photodegradation of neonicotinoids is one of the major abiotic degradation mechanisms, which provides information on the environmental stability of neonicotinoids following exposure of sunlight [43].

According to [31], photodegradation of imidacloprid often forms byproducts less harmful to non-target species; however, under certain conditions, toxic byproducts can be produced. 
For instance, imidacloprid and thiamethoxam were found to undergo photocatalytic degradation in a microcosm study using six polychromatic fluorescent UVA (355 nm) lamps and in a titanium dioxide $\left(\mathrm{TiO}_{2}\right)$ solution. Byproducts formed from imidacloprid included 6-chloronicotinic acid, imidacloprid hydroxyl, imidacloprid urea, and desnitro olefin, while thiamethoxam degraded into clothianidin and thiamethoxam urea (Figures 2 and 3) [9].

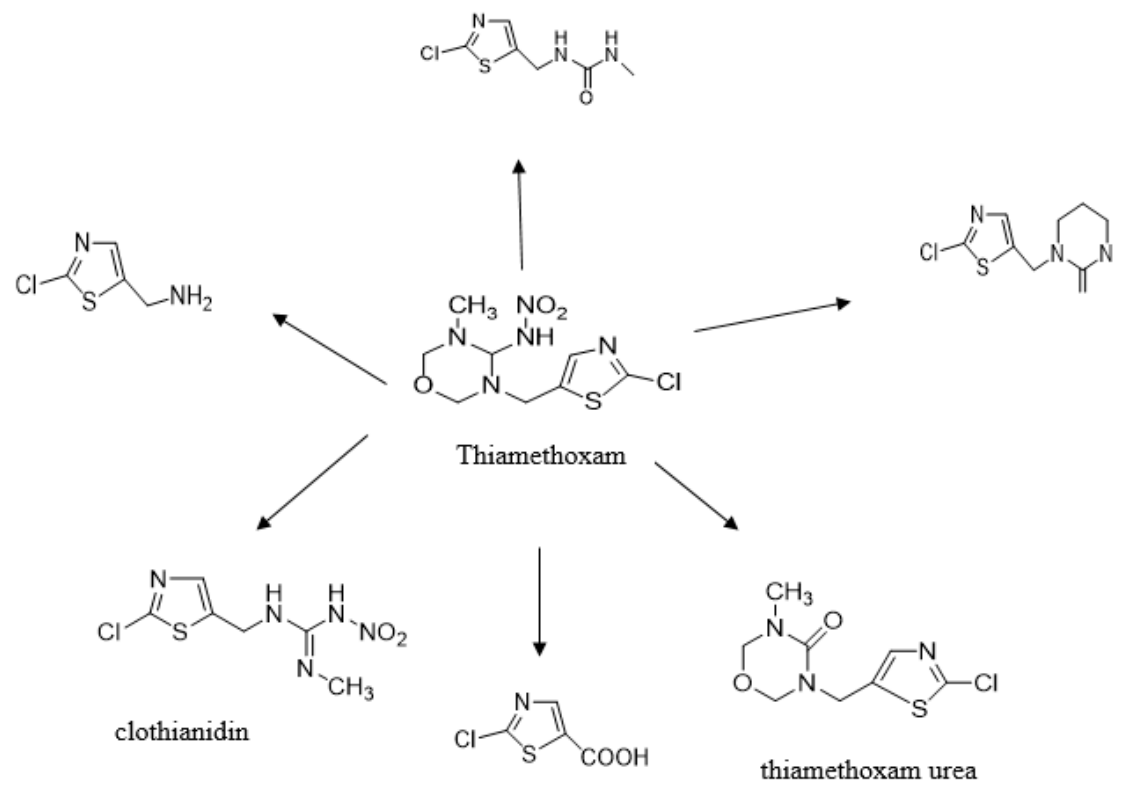

Figure 2. Byproduct of thiamethoxam photocatalytic degradation experiment (adapted from [43]).

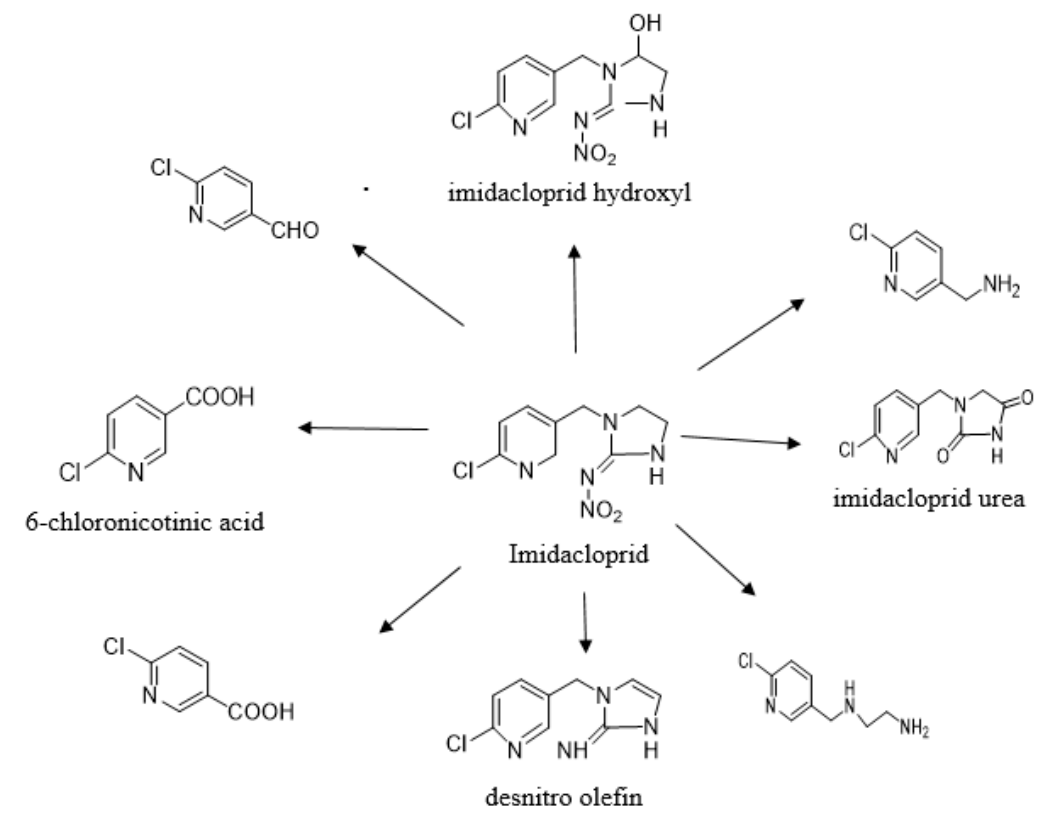

Figure 3. Byproduct of imidacloprid photocatalytic degradation experiment (adapted from [43]).

Another important parameter influencing the degradation of neonicotinoids in aquatic systems is $\mathrm{pH}$ [30]. To understand the effect of $\mathrm{pH}$ on the degradation of neonicotinoids, [44] studied four classes of neonicotinoids (acetamiprid, imidacloprid, thiacloprid, and thiamethoxam) at $23{ }^{\circ} \mathrm{C}$, where imidacloprid and thiamethoxam degraded rapidly under alkaline condition, while at $\mathrm{pH} 7$ and 4 the compounds remained relatively stable. In contrast, acetamiprid and thiacloprid degraded more rapidly in acidic conditions, but remained stable for approximately 30 days in alkaline conditions [30]. 
In surface water, the presence of dissolved organic carbon and suspended particulate matter have been found to also affect the rate of degradation of neonicotinoids in aquatic environments by mimicking the sorption process, thereby decreasing their degradation rate [36]. In contrast, in soil environments parameters such as half-life, soil-water partition $\left(K_{d}\right)$, percentage of soil organic carbon $(\% \mathrm{OC})$, soils adsorption coefficient $\left(K_{o c}\right)$ and octanol-water partition coefficient $\left(K_{o w}\right)$ affect the fate and transport of neonicotinoids $[45,46]$.

The most rapid degradation pathway for neonicotinoids in water is photodegradation; however, the degradation process is often limited due to factors such as water depth, light penetration, and microbial activities [26]. Other chemical properties impacting degradation of neonicotinoids in soil and water include high water solubility, low octanol-water partitioning coefficient $\left(\log K_{o w}\right)$ and low organic carbon partition coefficient $\left(\log K_{o c}\right)$ which enhance the movement of neonicotinoids through surface and subsurface runoff [22].

Few studies have investigated environmental persistence of post application of neonicotinoids. In natural and deionized water, photodegradation experiments of imidacloprid has been broadly investigated with various light sources in combination with either catalyst or photosensitizers, in which it has been expressed that imidacloprid is vulnerable to photodegradation adhering to either first-order or pseudo-first order kinetics [43]. Imidacloprid was found to readily undergo degradation with a first-order rate constant of $1.6 \times 10^{-4} S^{-1}$ and a half-life of $1.2 \mathrm{~h}$ under aqueous photolysis [47], which has been confirmed in other photolysis studies as well [31]. Laboratory-based photolysis studies of mixed solvents, such as acetonitrile and water with artificial sunlight from a $250 \mathrm{~W}$ sun lamp, have reported half-lives of imidacloprid to be $3.0 \mathrm{~h}$ [48]. Furthermore, when the mixtures are enriched with a photosensitizer such as titanium dioxide $\left(\mathrm{TiO}_{2}\right)$ and acetone imidacloprid photolysis is reduced. Further, [49] reported significant photodegradation of neonicotinoids insecticides, specifically thiamethoxam, in an aqueous solution experiment conducted using both sunlight and artificial light.

Kurwadkar [43] observed aqueous photodegradation of neonicotinoids in natural waters varied depending on the presence of DOM and other inorganic pollutants influencing photolysis by causing degradation to increase or decrease. Similarily, Zeng [50] reported that photodegradation in natural waters was affected by a diversity of photosensitizers including DOM, nitrate, nitrite, and impurities such as iron. The active portion of neonicotinoid insecticides undergoing photodegradation was typically the nitroguanidine group. In such case, the most important species relevant to the environmental fate and transport of these insecticides are the portions containing the molecular structures attached to the nitroguanidine group. However, the degradation byproducts of neonicotinoid compounds posing the greatest risk to the environment are typically those with the chloropyridine ring [43].

\section{Occurrence and Persistence of Neonicotinoids in Global Surface Waters}

For this review, 55 studies were reviewed from eight countries around the world to investigate the occurrence of neonicotinoids in streams, groundwater, and lakes, with most studies focusing on neonicotinoid occurrence in rivers [2,5,8,22,23,51-56] (Figure 4).

The first comprehensive study of neonicotinoids in surface water within an agricultural intensive region was completed in Southern Ontario, Canada, where fifteen sites were investigated including nine streams and six rivers [54]. Based on the federal guidelines set for neonicotinoids in Canada, over $90 \%$ of neonicotinoids were detected in over half of the fifteen sites between 2012 and 2014 [54]. Further, in predominately agricultural regions imidacloprid was detected at concentrations up to $11.9 \mu \mathrm{g} / \mathrm{L}$ [57]. Therefore, to better understand the widespread use of neonicotinoids in aquatic ecosystem, the U.S., Netherlands and Sweden carried out surveys regarding the presence of imidacloprid, thiamethoxam and acetamiprid in surface water [53,56]. Neonicotinoids were detected in $89-100 \%$ of surface water samples for imidacloprid, $31 \%$ of surface water samples for thiamethoxam and $17 \%$ of surface water samples for acetamiprid with concentrations ranging from 0.22 to $200 \mu \mathrm{g} \mathrm{L}^{-1}$, depending on the compound. Findings from the survey provided strong evidence for potential water-quality concerns in both surface 
and ground water in these regions [24]. Neonicotinoids are also being used in developing countries around the world. For example, in Bangladesh a dramatic shift to insecticide usage has occurred in agricultural regions over the last two decades [58]. Specifically, the use of neonicotinoids in Bangladesh has increased from 7350 metric tons in 1992 to 45,172 metric tons in 2010 [55]. On the global stage, neonicotinoids continue to dominate the insecticide market [14], which has resulted in more being observed in downstream aquatic environments [2].
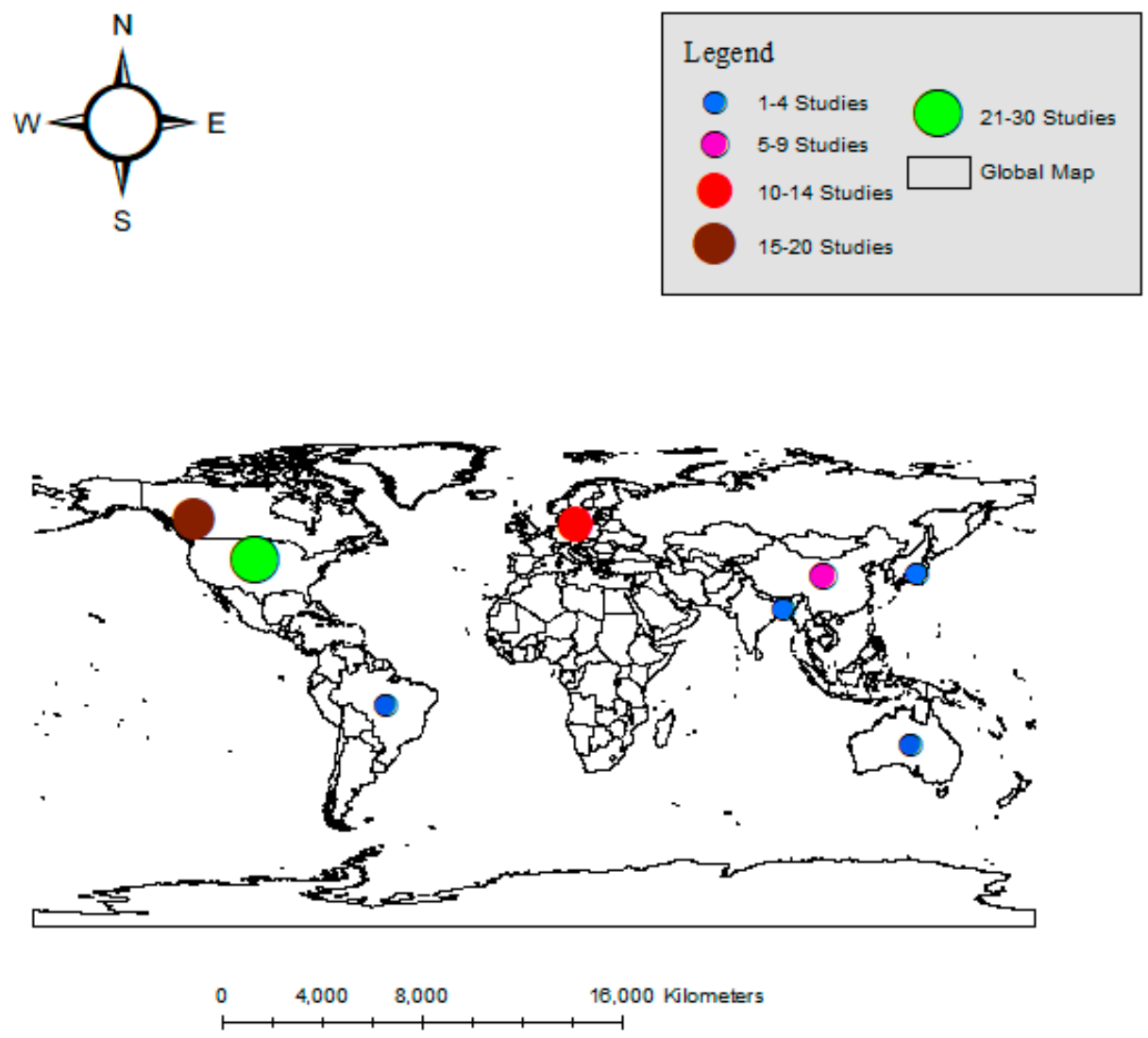

Figure 4. Locations of neonicotinoid studies around the world.

Many surface waters studies have been conducted, specifically in varying regions of the U.S. (Figure 5 Table 2). A recent study conducted by the U.S. Geological Survey (USGS) detected neonicotinoids in $53 \%$ of surface water samples collected from streams located in different regions of the country with imidacloprid most frequently detected ( $37 \%$ of samples) followed by clothianidin ( $24 \%$ of samples), and thiamethoxam (21\% of samples) [22]. Based on these findings, neonicotinoids are moving into water resources following the application by both seed treatment and/or liquid, thus posing potentially significant risks on surface water ecosystems [24]. 


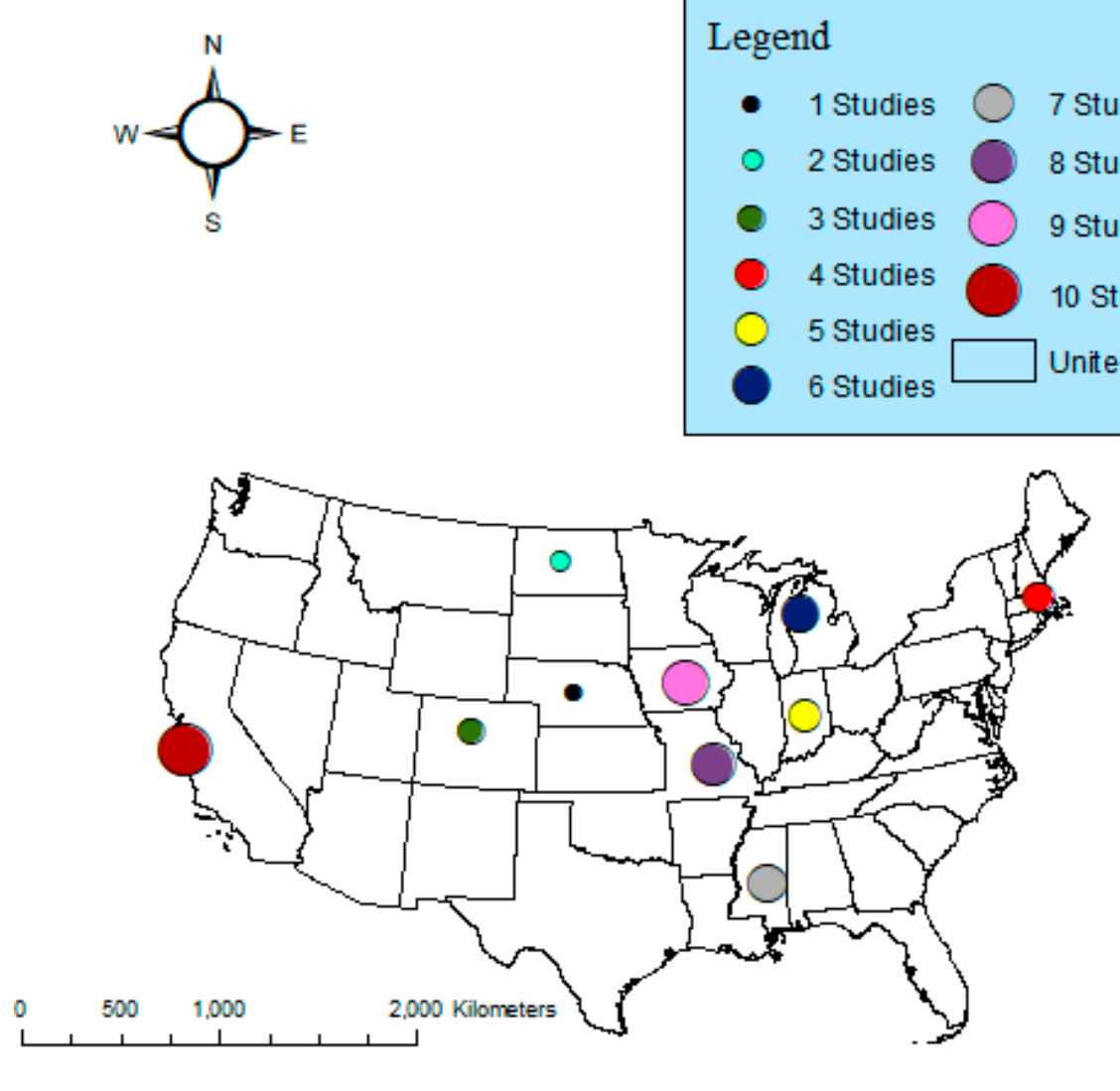

Figure 5. Map displaying neonicotinoid river study locations in the U.S. 
Table 2. Neonicotinoid concentrations recorded from surface water studies worldwide (ng/L).

\begin{tabular}{|c|c|c|c|c|c|c|c|c|c|}
\hline Study Location & Year & THM & IMI & ACE & CLO & THA & DNT & NTP & Reference \\
\hline Elkhorn River, Midwestern, USA & 2018-2019 (Range) & nd & $7-81$ & nd & $9-49$ & nd & nd & - & Ongoing study \\
\hline Neuse River, Southeastern USA & 2019 Median (Range) & nd & $14-42$ & nd & nd & nd & nd & nd & Ongoing study \\
\hline Nationwide River, USA & $\begin{array}{l}\text { 2012-2014 Range for } \\
38 \text { streams }\end{array}$ & nd-190 & nd-142 & nd-45.6 & nd-66.3 & nd & nd-13.8 & nd & [59] \\
\hline Seven Stream Basins, Iowa, USA & 2013 Median (Range) & $<($ nd-185) & $<2$ (nd-42.7) & nd & 8.2 (nd-257) & nd & nd & - & [2] \\
\hline Seven watersheds, Ontario, Canada & 2016 Range & nd-1607 & nd-1333 & nd-109 & nd-778 & nd-7 & nd-18 & nd & [60] \\
\hline Stream, Southern Ontario, Canada & 2012-2014 Range & $<1.4-12.9$ & $<1.3-364$ & $<0.2-8.5$ & $<1.8-31.4$ & $<0.5-7.97$ & - & - & [54] \\
\hline Pearl River, Guangzhou, China & 2017 Median (Range) & $30.6(4.97-102)$ & $31.0($ nd-180) & $17.1(3.13-67.6)$ & $16.6(0.55-67.2)$ & $1.33(\mathrm{nd}-12.4)$ & & & [51] \\
\hline Yangtze River, China & 2015 Median (Range) & 1.10 (nd-236) & $4.37(0.02-44.4)$ & $2.50(0.26-2.0)$ & $0.10($ nd-10.5) & 0.02 (nd-0.26) & nd & $0.34($ nd-3.50) & [5] \\
\hline River, Osaka, Japan & 2009-2010 Median & $2.65(\mathrm{nd}-11)$ & $5.55($ nd-25) & $1.4($ nd-1.4) & $3.2(\mathrm{nd}-12)$ & - & $20.0(3.7-220)$ & - & [61] \\
\hline River, Sydney, Australia & 2013 Median (Range) & 0.1 (nd-0.2) & 0.2 (nd-4.56) & 0.08 (nd-0.32) & 0.06 (nd-0.42) & 0.1 (nd-0.2) & nd & - & [24] \\
\hline
\end{tabular}

$\mathrm{nd}=$ not detected, THEM = thiamethoxam, IMI = imidacloprid, $\mathrm{ACE}=$ acetamiprid, $\mathrm{CLO}=$ clothianidin, $\mathrm{THA}=$ thiacloprid, $\mathrm{DNT}=$ dinotefuran, and NTP $=$ nitenpyram. 
A more recent nationwide survey in the U.S., conducted by the USGS, observed elevated neonicotinoids concentrations in streams and rivers sampled in California and Iowa urban regions. For example, imidacloprid, thiamethoxam and clothianidin concentrations were as high as 142.8, 190.4 and $38.2 \mu \mathrm{g} / \mathrm{L}$, respectively [59]. Further, a study conducted in 2013 in Iowa collected seventy-nine water samples in seven stream basins across the state during the growing season, where substantial corn (59\%) and soybean (86\%) production occurred within the Missouri and Mississippi River Basins [2]. Neonicotinoid occurrence in these regions was high, with the majority of detectable neonicotinoids being clothianidin, thiamethoxam, and imidacloprid, with less or no detection of other classes of neonicotinoids such as thiacloprid. Clothianidin was the most often detected insecticide with detection in $75 \%$ of stream samples, in regions with application rates of approximately $215,000 \mathrm{~kg}$, followed by thiamethoxam $(47 \% ; 49,900 \mathrm{~kg})$ and imidacloprid $(23 \% ; 70,700 \mathrm{~kg})$ [2].

In aquatic environments, neonicotinoids have the ability to persist for days to weeks prior to undergoing transport or degradation processes [62]. Neonicotinoids continue to be observed in downstream ecosystems years following their removal from the insecticide market such as in Europe [62], which emphasizes the need for a better understanding of neonicotinoid persistence following applications in aquatic systems.

\section{Toxicity of Neonicotinoids towards Organisms}

While the commercialization of neonicotinoids and their contribution to the global economy have been significant, concerns (e.g., surface and groundwater contamination, toxicity towards non-target organisms) associated with the extensive use of these products remain undisputed [9]. As the use of neonicotinoids continues to increase in many parts of the world, neonicotinoid products also continue to undergo increasing scrutiny. Table 3 reports the EPA's neonicotinoid toxicity limits for freshwater fish and invertebrates.

In aquatic ecosystems, neonicotinoids affect non-targeted sensitive aquatic invertebrates, significantly impacting aquatic food webs [63]. Sumon [57] conducted acute toxicity tests using ten macroinvertebrate samples belonging to three different taxonomic groups, which include Insecta (6 taxa), Phylum Mollusca (3 taxa) and Phylum Annelida (1 taxon) to evaluate the negative effects of imidacloprid on macroinvertebrate communities. Imidacloprid was reported to have significantly negative effects on insect species including Tubifex and Chironomid. Following a recent study of the effects of neonicotinoids on the environment, non-targeted organisms, water quality, and human health by the Canadian Pest Management Regulatory Agency (PMRA), a reevaluation of clothianidin, thiamethoxam, and imidacloprid was determined in order to further understand their toxicity levels on non-target species [8]. In this review, 22 studies were focused on the toxicity towards insects and invertebrates $[1,55,64,65]$. Four (4) out of fifty-five (55) rivers studies completed in Canada, Europe China, and the U.S. observed concentration levels above the chronic concentration limits for aquatic systems [15,51,57] (Figure 6). In Europe, the acute and chronic toxicity levels for aquatic environment are 0.2 and $0.0083 \mu \mathrm{g} / \mathrm{L}$ [66], while in Canada, the Canadian Council of Ministers of Environmental Water Quality Guideline toxicity level for aquatic environment is $0.230 \mu \mathrm{g} / \mathrm{L} \mathrm{[67].}$

Concern has also risen regarding the role of neonicotinoids to adversely affect pollinators, thereby resulting in honeybee colony collapse and disorder [68]. Bee colony collapse disorder has been characterized by sudden disappearance of honey bees from terrestrial ecosystems, which many scientists have attributed to factors including insecticides, pathogens, and natural habitat degradation [69,70]. According to [71] beekeepers lost approximately 10\% of their bee colonies in early spring of 2007 across 22 states in the U.S. Insecticides applied to agricultural fields were the possible cause of the colony collapse disorder in those environments. For example, thiamethoxam has been linked to decreased honeybee survival rate following exposure [72]. Imidacloprid occurrence has also been linked to reducing bumble bee colony growth and queen performance in the terrestrial environments [73], as well as being sublethal $\left(L D_{50}\right)$ to other non-target insects present in the surrounding ecosystem where the chemical is applied [74]. 
Table 3. Environmental Protection Agency's Office of Pesticide Programs toxicity limit in freshwater for fish and invertebrates. - means no benchmark available [66].

\begin{tabular}{ccccc}
\hline \multirow{2}{*}{ Compounds } & \multicolumn{2}{c}{ Fish } & \multicolumn{2}{c}{ Invertebrates } \\
\cline { 2 - 5 } & Acute $(\mu \mathrm{g} / \mathrm{L})$ & Chronic $(\mu \mathrm{g} / \mathrm{L})$ & Acute $(\mu \mathrm{g} / \mathrm{L})$ & Chronic $(\mu \mathrm{g} / \mathrm{L})$ \\
\hline Acetamiprid & $>50,000$ & 19,200 & 10.5 & 2.1 \\
Clothianidin & $>50,750$ & 9700 & 11 & 0.05 \\
Dinotefuran & $>49,550$ & 6360 & $>484,150$ & $>95,300$ \\
Imidacloprid & 114,500 & 9000 & 0.385 & 0.1 \\
Nitenpyram & - & - & - & - \\
Thiacloprid & 12,600 & 918 & 81.9 & 0.97 \\
Thiamethoxam & $>57,000$ & 20,000 & 17.5 & 0.74 \\
\hline
\end{tabular}
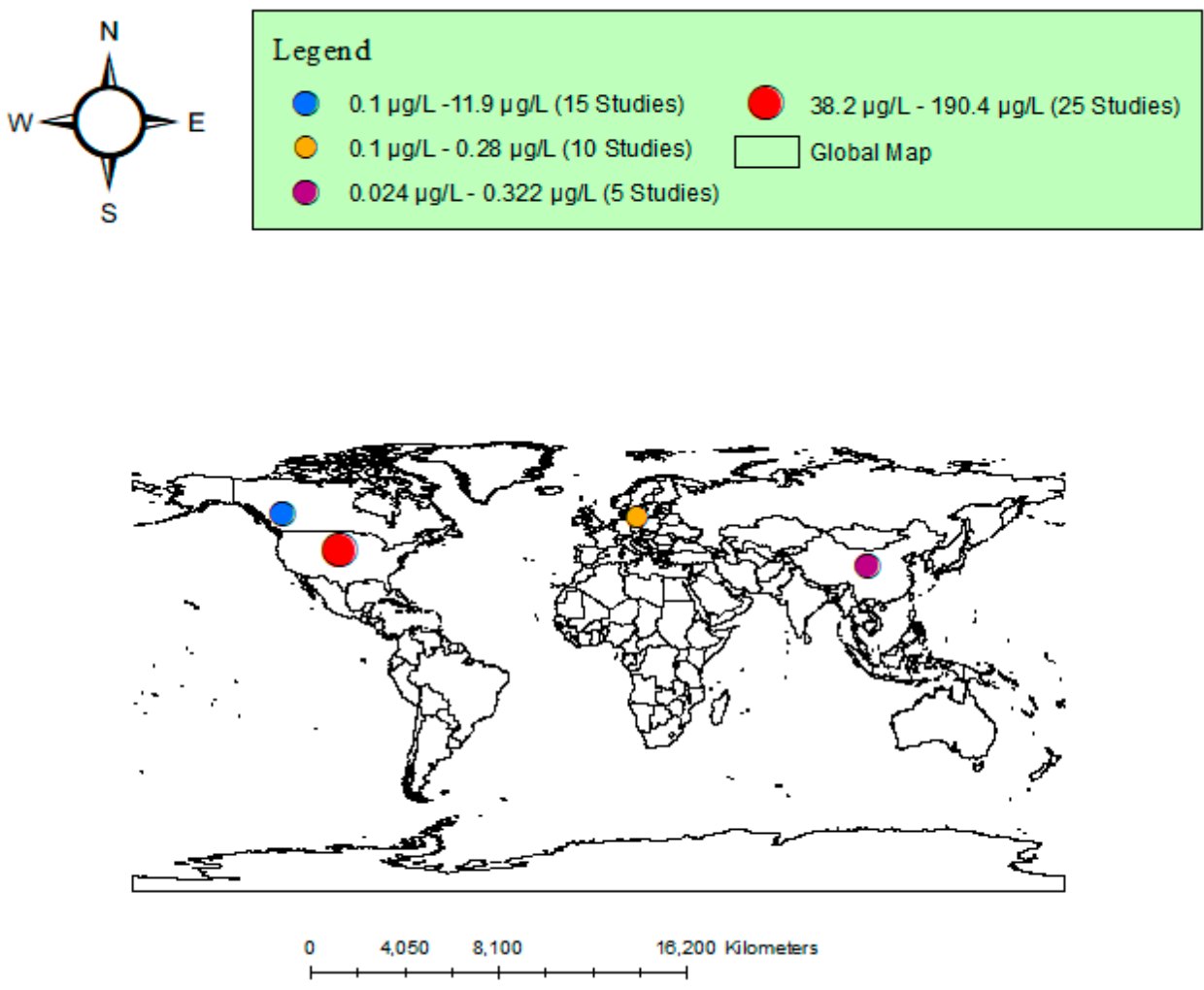

Figure 6. Neonicotinoid concentrations detected with few exceeding chronic concentration limits in aquatic systems.

\section{Exposure Risks to Humans}

Neonicotinoids are applied in the environment by either spraying, drip irrigation, or seed treatments, resulting in potential exposure to humans by means of atmospheric contamination (e.g., inhalation) [75]. Individuals who are not in direct contact with neonicotinoids have the potential for exposure to the chemicals through dietary ingestion from eating fruits and vegetables harvested from agricultural land where neonicotinoids were applied. From 29 samples of fruits and vegetables, neonicotinoids were detected in $72 \%$ of the fruits and $45 \%$ of the vegetables [76]. Additionally, neonicotinoids have high water solubility, which could result in ingestion exposure to humans through drinking water contamination [75].

These systemic insecticides are poisonous at high concentrations to the nervous system especially liver, kidney, thyroid, testicular, and are most likely carcinogenic to humans at high concentrations [75]. In order to address insecticides in relation to health-related concerns associated with human exposure to neonicotinoids through ingestion, international organizations and several countries have set lower 
acceptance levels of these chemicals in food which vary from country to country. The Codex Committee on Pesticides Residues (CCPR) is a supplementary body of Codex Alimentarius Commission (CAC) that is charged with the primary responsibility of providing advice on pesticides residues in food [77]. Their major objective is to develop the maximum residue limits (MRLs) for countries including the European Union (EU), China, and Japan [77]. MRLs are fixed by applying the Best Agricultural Practices in the field and then compared with the results of the risk assessment of pesticides residues in food in the worst-case scenario referred to as the Theoretical Maximum Daily Intake (TMDI). TMDI calculations often result in a gross overestimation of intake and are compared with the Acceptable Daily Intake (ADI) that is a toxicological indirect parameter. For example, the MRLs in EU countries for imidacloprid and thiamethoxam are 0.05 and $20 \mathrm{mg} / \mathrm{kg}$, respectively. In contrast, in China, the MRL for imidacloprid is $0.5 \mathrm{mg} / \mathrm{kg}$, while 10 and $15 \mathrm{mg} / \mathrm{kg}$ are the MRLs for imidacloprid and thiamethoxam in Japan, respectively [78]. Therefore, humans are potentially exposed to unsafe levels of insecticide residues in their food products on a daily basis, even though the ADI of pesticide in certain food in one country are considered unacceptable within specific countries [78].

Further, the long-term exposure implications are relatively unknown given limited data and time since their entrance to the pesticide market and are needed to be further evaluated. In 2013, the European Union countries expanded its ban on neonicotinoids insecticides (e.g., clothianidin, imidacloprid, thiamethoxam) due to the growing concern of their potentially significant threat to non-target insects such as honeybees [79]. The ban was implemented by E.U. member states-a total of sixteen countries including the United Kingdom, France, and Germany voted in favor of the ban, while Romania, Demark, and three other countries voted against the ban, and 13 countries remained neutral [79].

\section{Future Work/Knowledge Gap}

In conclusion, we reviewed 55 articles that focused on the occurrence and/or fate and transport of neonicotinoids in realistic aquatic environments and 22 articles that focused on the toxicity towards insects and invertebrates. This comprehensive review provides a foundation for improving our understanding of neonicotinoid usage and potential impacts on non-target species and the natural environment at the global scale. This review serves as a useful tool for identifying regions that may need enhanced development of best management practices (BMPs) to mitigate the negative consequences associated with extensive use of insecticides in surface and groundwater. Specifically, the U.S. had significantly higher concentrations of insecticides compared to other reviewed regions. Therefore, we recommend further investigation of neonicotinoids at both micro and macro scales.

A substantial amount of research has been completed to investigate the occurrence of neonicotinoids in aquatic environments and degradation of these insecticides under laboratory conditions. Findings from this work have the potential to aide in best management practice development and implementation for identifying potential fate and transport scenarios for these insecticides. However, the impacts of field conditions on the degradation of neonicotinoids remains not well understood. Therefore, future investigations are needed to:

1) Quantify the potential roles of realistic field conditions on degradation along various neonicotinoid insecticide fate and transport scenarios.

2) Improve our understanding of the role of river geomorphology on photochemical transformation and degradation of neonicotinoids along path-specific environmental conditions.

3) Investigate the long-term exposure implications to non-target organisms (including humans).

Author Contributions: Conceptualization, methodology, validation, formal analysis, J.F.B. and T.L.M.; software, visualization, J.F.B. and A.R.M.; investigation, resources, data curation, writing-original draft preparation, J.F.B.; writing-review and editing, J.F.B., T.L.M., A.R.M., D.D.S. and S.D.C.; supervision, project administration, funding acquisition, T.L.M. All authors have read and agreed to the published version of the manuscript. 
Funding: This article is based upon work that was supported by the National Institute of Food and Agriculture, U.S. Department of Agriculture, under award number 2018-67019-27794, and a Hatch multistate capacity funding grant (W-4045). Any opinions, findings, conclusions, or recommendations expressed in this publication are those of the authors and do not necessarily reflect the view of the U.S. Department of Agriculture.

Acknowledgments: Collaborators that made this project possible include the Jessica Satiroff, Levi McKercher, Julia Lindgren, Brittany Trejo, Nayelly Rodriguez, Matthew Russell, Ken Oathout, and Keima Kamara-Borsuah.

Conflicts of Interest: The authors declare no conflict of interest.

\section{References}

1. Blacquière, T.; Smagghe, G.; Van Gestel, C.A.M.; Mommaerts, V. Neonicotinoids in bees: A review on concentrations, side-effects and risk assessment. Ecotoxicology 2012, 21, 973-992. [CrossRef]

2. Hladik, M.L.; Kolpin, D.W.; Kuivila, K.M. Widespread occurrence of neonicotinoid insecticides in streams in a high corn and soybean producing region, USA. Environ. Pollut. 2014, 193, 189-196. [CrossRef] [PubMed]

3. Goulson, D. An overview of the environmental risks posed by neonicotinoid insecticides. J. Appl. Ecol. 2013, 50, 977-987. [CrossRef]

4. Elbert, A.; Nauen, R.; Leicht, W. Imidacloprid, a novel chloronicotinyl insecticide: Biological activity and agricultural importance. In Insecticides with Novel Modes of Action; Springer: Berlin/Heidelberg, Germany, 1998; pp. 50-73.

5. Mahai, G.; Wan, Y.; Xia, W.; Yang, S.; He, Z.; Xu, S. Neonicotinoid insecticides in surface water from the central Yangtze River, China. Chemosphere 2019, 229, 452-460. [CrossRef]

6. Jeschke, P.; Nauen, R.; Schindler, M.; Elbert, A. Overview of the status and global strategy for neonicotinoids. J. Agric. Food Chem. 2011, 59, 2897-2908. [CrossRef]

7. Jeschke, P.; Nauen, R. Thiamethoxam: A neonicotinoid precursor converted to clothianidin in insects and plants. Acs Symp. Ser. 2007, 948, 51-65.

8. Anderson, J.C.; Dubetz, C.; Palace, V.P. Neonicotinoids in the Canadian aquatic environment: A literature review on current use products with a focus on fate, exposure, and biological effects. Sci. Total Environ. 2015, 505, 409-422. [CrossRef]

9. Žabar, R.; Komel, T.; Fabjan, J.; Kralj, M.B.; Trebše, P. Photocatalytic degradation with immobilised $\mathrm{TiO}_{2}$ of three selected neonicotinoid insecticides: Imidacloprid, thiamethoxam and clothianidin. Chemosphere 2012, 89, 293-301. [CrossRef]

10. Craddock, H.A.; Huang, D.; Turner, P.C.; Quirós-Alcalá, L.; Payne-Sturges, D.C. Trends in neonicotinoid pesticide residues in food and water in the United States, 1999-2015. Environ. Heal. Glob. Access Sci. Source 2019, 18, 1-16. [CrossRef]

11. Aktar, W.; Sengupta, D.; Chowdhury, A. Impact of pesticides use in agriculture: Their benefits and hazards. Interdiscip. Toxicol. 2009, 2, 1-12. [CrossRef]

12. Pisa, L.W.; Amaral-Rogers, V.L.; Belzunces, P.; Bonmatin, J.M.; Downs, C.A.; Goulson, D.; Kreutzweiser, D.P.; Krupke, C.; Liess, M.; McField, M.; et al. Effects of neonicotinoids and fipronil on non-target invertebrates. Environ. Sci. Pollut. Res. 2014, 22, 68-102. [CrossRef]

13. Radolinski, J.; Wu, J.; Xia, K.; Hession, W.C.; Stewart, R.D. Plants mediate precipitation-driven transport of a neonicotinoid pesticide. Chemosphere 2019, 222, 445-452. [CrossRef]

14. Simon-Delso, N.; Amaral-Rogers, V.; Belzunces, L.P.; Bonmatin, J.M.; Chagnon, M.; Downs, C.; Furlan, L.; Gibbons, D.W.; Giorio, C.; Girolami, V.; et al. Systemic insecticides (Neonicotinoids and fipronil): Trends, uses, mode of action and metabolites. Environ. Sci. Pollut. Res. 2015, 22, 5-34. [CrossRef]

15. Sultana, T.; Murray, C.; Kleywegt, S.; Metcalfe, C.D. Neonicotinoid pesticides in drinking water in agricultural regions of southern Ontario, Canada. Chemosphere 2018, 202, 506-513. [CrossRef]

16. Ford, K.A.; Casida, J.E. Unique and common metabolites of thiamethoxam, clothianidin, and dinotefuran in mice. Chem. Res. Toxicol. 2006, 19, 1549-1556. [CrossRef]

17. Tomizawa, M.; Casida, J.E. S elective T oxicity of N eonicotinoids a tributable to S pecificity of I Nsect and M ammalian N icotinic, R. eceptors. Annu. Rev. Entomol. 2003, 48, 339-364. [CrossRef]

18. Duke, S.O.; Powles, S.B. Glyphosate: A once-in-a-century herbicide. Pest. Manag. Sci. 2008, 63, 1100-1106. [CrossRef] 
19. Kanne, D.B.; Dick, R.A.; Tomizawa, M.; Casida, J.E. Neonicotinoid nitroguanidine insecticide metabolites: Synthesis and nicotinic receptor potency of guanidines, aminoguanidines, and their derivatives. Chem. Res. Toxicol. 2005, 18, 1479-1484. [CrossRef]

20. Karlin, A. Ion channel structure: Emerging structure of the nicotinic acetylcholine receptors. Nat. Rev. Neurosci. 2002, 3, 102-114. [CrossRef]

21. Atsuda, K.M.; Himomura, M.S.; Hara, M.I.; Kamatsu, M.A.; Attelle, D.B.S. Neonicotinoids show selective and diverse actions on their nicotinic receptor targets: Electrophysiology, molecular biology, and receptor modeling studies I. insect nicotinic acetylcholine receptors II. physicochemical and structural proper-ties of. Receptor 2005, 69, 1442-1452.

22. Morrissey, C.A.; Mineau, P.; Devries, J.H.; Sanchez-Bayo, F.; Liess, M.; Cavallaro, M.C.; Liber, K. Neonicotinoid contamination of global surface waters and associated risk to aquatic invertebrates: A review. Environ. Int. 2015, 74, 291-303. [CrossRef]

23. Miranda, G.R.B.; Raetano, C.G.; Silva, E.; Daam, M.A.; Cerejeira, M.J. Environmental fate article: Environmental fate of neonicotinoids and classification of their potential risks to hypogean, epygean, and surface water ecosystems in Brazil. Hum. Ecol. Risk Assess. 2011, 17, 981-995. [CrossRef]

24. Sánchez-Bayo, F.; Hyne, R.V. Detection and analysis of neonicotinoids in river waters-Development of a passive sampler for three commonly used insecticides. Chemosphere 2014, 99, 143-151. [CrossRef]

25. Robin, S.U.R.; Stork, A. Uptake, translocation and metabolism of imidacloprid in plants. Bull. Insectology 2003, 56, 35-40.

26. Tišler, T.; Jemec, A.; Mozetič, B.; Trebše, P. Hazard identification of imidacloprid to aquatic environment. Chemosphere 2009, 76, 907-914. [CrossRef]

27. Lamers, M.; Anyusheva, M.; La, N.; Nguyen, V.V.; Streck, T. Pesticide Pollution in Surface-and Groundwater by Paddy Rice Cultivation: A Case Study from Northern Vietnam. Clean Soil Air Water 2011, 39, 356-361. [CrossRef]

28. Gupta, S.; Gajbhiye, V.T.; Agnihotri, N.P. Leaching behavior of imidacloprid formulations in soil. Bull. Environ. Contam. Toxicol. 2002, 68, 502-508. [CrossRef]

29. Huseth, A.S.; Groves, R.L. Environmental fate of soil applied neonicotinoid insecticides in an irrigated potato agroecosystem. PLoS ONE 2014, 9, e97081. [CrossRef]

30. Bonmatin, J.M.; Giorio, C.; Girolami, V.; Goulson, D.; Kreutzweiser, D.P.; Krupke, C.; Liess, M.; Long, E.; Marzaro, M.; Mitchell, E.A.D.; et al. Environmental fate and exposure; neonicotinoids and fipronil. Environ. Sci. Pollut. Res. 2015, 22, 35-67. [CrossRef]

31. Wamhoff, H.; Schneider, V. Photodegradation of imidacloprid. J. Agric. Food Chem. 1999, 47, 1730-1734. [CrossRef]

32. Comfort, S.D.; Shea, P.J.; Roeth, F.W. Understanding pesticides and water quality in Nebraska. EC (Nebraska Cooperative Extension Service). 1994. Available online: https://digitalcommons.unl.edu/ extensionhist/1635/ (accessed on 27 November 2020).

33. Carbo, L.; Martins, E.L.; Dores, E.F.G.C.; Spadotto, C.A.; Weber, O.L.S.; De-Lamonica-Freire, E.M. Acetamiprid, carbendazim, diuron and thiamethoxam sorption in two Brazilian tropical soils. J. Environ. Sci. Health Part $B$ Pestic. Food Contam. Agric. Wastes 2007, 42, 499-507. [CrossRef]

34. Banerjee, K.; Patil, S.H.; Dasgupta, S.; Oulkar, D.P.; Adsule, P.G. Sorption of thiamethoxam in three Indian soils. J. Environ. Sci. Health Part B Pestic. Food Contam. Agric. Wastes 2008, 43, 151-156. [CrossRef]

35. Wettstein, F.E.; Kasteel, R.; Garcia Delgado, M.F.; Hanke, I.; Huntscha, S.; Balmer, M.E.; Bucheli, T.D. Leaching of the neonicotinoids thiamethoxam and imidacloprid from sugar beet seed dressings to subsurface tile drains. J. Agric. Food Chem. 2016, 64, 6407-6415. [CrossRef]

36. Peña, A.; Rodríguez-Liébana, J.A.; Mingorance, M.D. Persistence of two neonicotinoid insecticides in wastewater, and in aqueous solutions of surfactants and dissolved organic matter. Chemosphere 2011, 84, 464-470. [CrossRef]

37. Dabrowski, J.M.; Peall, S.K.C.; Van Niekerk, A.; Reinecke, A.J.; Day, J.A.; Schulz, R. Predicting runoff-induced pesticide input in agricultural sub-catchment surface waters: Linking catchment variables and contamination. Water Res. 2002, 36, 4975-4984. [CrossRef]

38. Zhang, P.; Ren, C.; Sun, H.; Min, L. Sorption, desorption and degradation of neonicotinoids in four agricultural soils and their effects on soil microorganisms. Sci. Total Environ. 2018, 615, 59-69. [CrossRef] 
39. Balsari, P.; Marucco, P. Internal and external contamination of sprayers: Causes and strategies to minimise negative effects on the environment. Chem. Eng. Trans. 2017, 58, 793-798.

40. Occurrence, P. Pesticides in the Nation's Streams and Ground Water, 1992-2001-A Summary; USGS: Reston, VA, USA, 2006.

41. Hallberg, G.R. Pesticides pollution of groundwater in the humid United States. Agric. Ecosyst. Environ. 1989, 26, 299-367. [CrossRef]

42. Reichenberger, S.; Bach, M.; Skitschak, A.; Frede, H.G. Mitigation strategies to reduce pesticide inputs into ground- and surface water and their effectiveness: A review. Sci. Total Environ. 2007, 384, 1-35. [CrossRef]

43. Kurwadkar, S.; Evans, A.; DeWinne, D.; White, P.; Mitchell, F. Modeling photodegradation kinetics of three systemic neonicotinoids-Dinotefuran, imidacloprid, and thiamethoxam-In aqueous and soil environment. Environ. Toxicol. Chem. 2016, 35, 1718-1726. [CrossRef]

44. Guzsvány, V.; Csanádi, J.; Gaál, F. NMR study of the influence of pH on the persistence of some neonicotinoids in water. Acta Chim. Slov. 2006, 53, 52-57.

45. Kumar, S. Estimating spatial distribution of soil organic carbon for the Midwestern United States using historical database. Chemosphere 2015, 127, 49-57. [CrossRef]

46. Satkowski, L.E.; Goyne, K.W.; Anderson, S.H.; Lerch, R.N.; Webb, E.B.; Snow, D.D. Imidacloprid Sorption and Transport in Cropland, Grass Buffer, and Riparian Buffer Soils. Vadose Zone J. 2018, 17, 170139. [CrossRef]

47. Moza, P.N.; Hustert, K.; Feicht, E.; Kettrup, A. Photolysis of imidacloprid in aqueous solution. Chemosphere 1998, 36, 497-502. [CrossRef]

48. Sakata, S.; Mikami, N.; Matsuda, T.; Miyamoto, J. Degradation and Leaching Behavior of the Pyrethroid Insecticide Cypermethrin in Soils. J. Pestic. Sci. 1986, 11, 71-79. [CrossRef]

49. Schwartz, B.J.; Sparrow, F.K.; Heard, N.E.; Thede, B.M. Simultaneous derivatization and trappning of volatile products from aqueous photolysis of thiamethoxam insecticide. J. Agric. Food Chem. 2000, 48, 4671-4675. [CrossRef]

50. Zeng, T.; Arnold, W.A. Pesticide photolysis in prairie potholes: Probing photosensitized processes. Environ. Sci. Technol. 2013, 47, 6735-6745. [CrossRef]

51. Zhang, C.; Tian, D.; Yi, X.; Zhang, T.; Ruan, J.; Wu, R.; Chen, C.; Huang, M.; Ying, G. Occurrence, distribution and seasonal variation of five neonicotinoid insecticides in surface water and sediment of the Pearl Rivers, South China. Chemosphere 2019, 217, 437-446. [CrossRef]

52. Sánchez-Bayo, F.; Goka, K.; Hayasaka, D. Contamination of the aquatic environment with neonicotinoids and its implication for ecosystems. Front. Environ. Sci. 2016, 4, 71. [CrossRef]

53. Starner, K.; Goh, K.S. Detections of the neonicotinoid insecticide imidacloprid in surface waters of three agricultural regions of California, USA, 2010-2011. Bull. Environ. Contam. Toxicol. 2012, 88, 316-321. [CrossRef]

54. Struger, J.; Grabuski, J.; Cagampan, S.; Sverko, E.; McGoldrick, D.; Marvin, C.H. Factors influencing the occurrence and distribution of neonicotinoid insecticides in surface waters of southern Ontario, Canada. Chemosphere 2017, 169, 516-523. [CrossRef]

55. Ali, M.H.; Sumon, K.A.; Sultana, M.; Rashid, H. Toxicity of cypermethrin on the embryo and larvae of Gangetic mystus, Mystus cavasius. Environ. Sci. Pollut. Res. 2018, 25, 3193-3199. [CrossRef]

56. Van Dijk, T.C.; Van Staalduinen, M.A.; Van der Sluijs, J.P. Macro-Invertebrate Decline in Surface Water Polluted with Imidacloprid. PLoS ONE 2013, 8, e62374. [CrossRef]

57. Sumon, K.A.; Ritika, A.K.; Peeters, E.T.; Rashid, H.; Bosma, R.H.; Rahman, M.S.; Fatema, K.M.; Van den Brink, P.J. Effects of imidacloprid on the ecology of sub-tropical freshwater microcosms. Environ. Pollut. 2018, 236, 432-441. [CrossRef]

58. Rahman, S. Pesticide consumption and productivity and the potential of IPM in Bangladesh. Sci. Total Environ. 2013, 445, 48-56. [CrossRef]

59. Hladik, M.L.; Kolpin, D.W. First national-scale reconnaissance of neonicotinoid insecticides in streams across the USA. Environ. Chem. 2016, 13, 12-20. [CrossRef]

60. Metcalfe, C.D.; Helm, P.; Paterson, G.; Kaltenecker, G.; Murray, C.; Nowierski, M.; Sultana, T. Pesticides related to land use in watersheds of the Great Lakes basin. Sci. Total Environ. 2019, 648, 681-692. [CrossRef]

61. Yamamoto, A.; Terao, T.; Hisatomi, H.; Kawasaki, H.; Arakawa, R. Evaluation of river pollution of neonicotinoids in Osaka City (Japan) by LC/MS with dopant-assisted photoionisation. J. Environ. Monit. 2012, 14, 2189-2194. [CrossRef] 
62. Hauer, M.; Hansen, A.L.; Manderyck, B.; Olsson, Å.; Raaijmakers, E.; Hanse, B.; Stockfischa, N.; Märländer, B. Neonicotinoids in sugar beet cultivation in Central and Northern Europe: Efficacy and environmental impact of neonicotinoid seed treatments and alternative measures. Crop. Prot. 2017, 93, 132-142. [CrossRef]

63. Gibbons, D.; Morrissey, C.; Mineau, P. A review of the direct and indirect effects of neonicotinoids and fipronil on vertebrate wildlife. Environ. Sci. Pollut. Res. 2015, 22, 103-118. [CrossRef]

64. Han, W.; Tian, Y.; Shen, X. Human exposure to neonicotinoid insecticides and the evaluation of their potential toxicity: An overview. Chemosphere 2018, 192, 59-65. [CrossRef]

65. Raby, M.; Nowierski, M.; Perlov, D.; Zhao, X.; Hao, C.; Poirier, D.G.; Sibley, P.K. Acute toxicity of 6 neonicotinoid insecticides to freshwater invertebrates. Environ. Toxicol. Chem. 2018, 37, 1430-1445. [CrossRef]

66. USEPA. Aquatic Life Benchmarks and Ecological Risk Assessments for Registered Pesticides|Pesticide Science and Assessing Pesticide Risks|US EPA. 2017. Available online: https://www.epa.gov/pesticide-science-andassessing-pesticide-risks/aquatic-life-benchmarks-and-ecological-risk (accessed on 27 November 2020).

67. CCME. Canadian Environmental Quality Guidelines. 2017. Available online: https://www.ccme.ca/en/ resources/canadian_environmental_quality_guidelines/ (accessed on 27 November 2020).

68. Spivak, M.; Mader, E.; Vaughan, M.; Euliss, N.H., Jr. The plight of the bees. Environ. Sci. Technol. 2011, 45, 34-38. [CrossRef]

69. Cox-foster, D.L.; Conlan, S.; Holmes, E.C.; Palacios, G.; Evans, J.D.; Moran, N.A.; Phenix-Lan, Q.; Briese, T.; Hornig, M.; Martinson, V. Collapse disorder. Science 2007, 318, 283-288. [CrossRef]

70. Naug, D. Nutritional stress due to habitat loss may explain recent honeybee colony collapses. Biol. Conserv. 2009, 142, 2369-2372. [CrossRef]

71. Oldroyd, B.P. What's killing American honey bees? PLoS Biol. 2007, 5, 1195-1199. [CrossRef]

72. Henry, M.; Beguin, M.; Requier, F.; Rollin, O.; Odoux, J.F.; Aupinel, P.; Aptel, J.; Tchamitchian, S.; Decourtye, A. A common pesticide decreases foraging success and survival in honey bees. Science 2012, 336, 348-350. [CrossRef]

73. Whitehorn, P.R.; O'Connor, S.; Wackers, F.L.; Goulson, D. Neonicotinoid pesticide reduces bumble bee colony growth and queen production. Science 2012, 336, 351-352. [CrossRef]

74. Charpentier, G.; Louat, F.; Bonmatin, J.M.; Marchand, P.A.; Vanier, F.; Locker, D.; Decoville, M. Lethal and sublethal effects of imidacloprid, after chronic exposure, on the insect model drosophila melanogaster. Environ. Sci. Technol. 2014, 48, 4096-4102. [CrossRef]

75. Zhang, Q.; Li, Z.; Chang, C.H.; Lou, J.L.; Zhao, M.R.; Lu, C. Potential human exposures to neonicotinoid insecticides: A review. Environ. Pollut. 2018, 236, 71-81. [CrossRef]

76. Chen, M.; Tao, L.; McLean, J.; Lu, C. Quantitative analysis of neonicotinoid insecticide residues in foods: Implication for dietary exposures. J. Agric. Food Chem. 2014, 62, 6082-6090. [CrossRef]

77. WHO. Guidelines for Predicting Dietary Intake of Pesticide Residues; WHO: Geneva, Switzerland, 1997; p. 41.

78. Hou, R.Y.; Hu, J.F.; Qian, X.S.; Su, T.; Wang, X.H.; Zhao, X.X.; Wan, X.C. Comparison of the dissipation behaviour of three neonicotinoid insecticides in tea. Food Addit. Contam. Part A Chem. Anal. Control. Expo. Risk Assess. 2013, 30, 1761-1769. [CrossRef]

79. Storkstad, E. European Union Expands Ban of Three Neonicotinoid Pesticides|Science|AAAS. 2018. Available online: https://www.sciencemag.org/news/2018/04/european-union-expands-ban-three-neonicotinoidpesticides (accessed on 27 November 2020).

Publisher's Note: MDPI stays neutral with regard to jurisdictional claims in published maps and institutional affiliations.

(C) 2020 by the authors. Licensee MDPI, Basel, Switzerland. This article is an open access article distributed under the terms and conditions of the Creative Commons Attribution (CC BY) license (http://creativecommons.org/licenses/by/4.0/). 